\title{
Thermal decomposition of $d$-metal nitrates supported on alumina
}

\author{
Barbara Małecka • Agnieszka Lącz • \\ Ewa Drożdż $\cdot$ Andrzej Małecki
}

Received: 13 July 2014/ Accepted: 20 October 2014/Published online: 28 November 2014

(C) The Author(s) 2014. This article is published with open access at Springerlink.com

\begin{abstract}
The thermal decomposition of cobalt, nickel, manganese, zinc, and copper nitrates supported on nanometric alumina was investigated and compared with decomposition of corresponding bulk nitrates. TG, DTA, and MS measurements in air were performed. The supported nitrates decompose in lower temperatures than the bulk ones and their decomposition proceeds in fewer stages which are better separated. Synthesized materials and bulk nitrates before degradation of nitrates groups undergo dehydration. For decomposition of manganese and copper nitrates, the last step of water vapour releasing is combined with degradation of nitrate groups thus formation of anhydrous metal nitrate during decomposition is not achievable. Thermal decomposition of bulk nitrates leads to oxides- $\mathrm{Co}_{3} \mathrm{O}_{4}, \mathrm{NiO}, \mathrm{MnO}_{2}, \mathrm{ZnO}$, and $\mathrm{CuO}-$ respectively, as the solid residue. The nickel, zinc, copper, and manganese nitrates while supported on alumina decompose to corresponding oxides $\left(\mathrm{NiO}, \mathrm{ZnO}, \mathrm{CuO}, \mathrm{MnO}_{2}\right)$ as well. For decomposition of cobalt nitrate while supported on $\mathrm{Al}_{2} \mathrm{O}_{3}$ as the solid residue $\mathrm{CoAl}_{2} \mathrm{O}_{4}$ were identified. The correlation between dehydration and degradation of nitrates groups temperatures for bulk and supported nitrates was analysed in terms of atomic properties of $d$-metals.
\end{abstract}

Keywords $d$-Metal nitrates - Thermal decomposition . Supported nitrates $\cdot$ Impregnation $\cdot$ Mass spectrometry

Barbara Małecka-Deceased.

B. Małecka · A. Łącz (凹) · E. Drożdż · A. Małecki Faculty of Materials Science and Ceramics, AGH University of Science and Technology, 30 Mickiewicz Av., 30-059 Kraków, Poland

e-mail: alacz@agh.edu.pl

\section{Introduction}

Metal oxide submicrometer particles have received widespread interest recently because of their envisioned applications in electronics, optics, and magnetic storage devices as well as materials for catalytic applications $[1,2]$. The properties of metal oxide catalysts, such as specific surface area, phase composition, particle size, porosity, and activity are greatly affected by the conditions chosen for their preparation [3]. The kind of precursor materials, temperature, and duration of heat treatment as well as the composition of surrounding atmosphere are important parameters.

Metal nitrates hydrates are very often used as the precursors of metal oxides because they give materials of well-defined chemical composition and high specific surface area [4-9]. The advantage of nitrates compared to chlorides or sulphates is that they can be fully converted to corresponding oxides. However, conditions for the synthesis of metal oxides having appropriate properties usually have to be found experimentally [10].

The decomposition of $d$-metal nitrates hydrates proceeds by stages and rarely leads to anhydrous salt. Usually the dehydration process is not complete and the beginning of nitrate(V) groups decomposition occurs simultaneously with hydration water evolution [11-15]. The mechanism of $d$-metal nitrates hydrates decomposition is rather complicated and proceeds in different ways depending on whether the gas atmosphere is oxidizing, neutral or reducing. The complete decomposition resulting in metal oxide formation is usually finished below $300{ }^{\circ} \mathrm{C}$ [16]. In moist atmosphere, the decomposition of $d$-metal nitrates can occur at lower temperatures than in dry atmosphere [17].

High specific surface area metal oxides can be synthesized by a route involving impregnation of different types 
of porous materials, like alumina, carbon, clay, zeolite or silica, with concentrated metal salt solutions and subsequent thermal treatment $[18,19]$. This route allows the synthesis of a wide variety of different metal oxides, either as defined phases, if suitably chosen amounts of precursor salts are used, or as amorphous or partially crystalline multiple mixed-metal oxides. Typically, specific surface areas in the range between 50 and $200 \mathrm{~m}^{2} \mathrm{~g}^{-1}$ are accessible, and in addition to crystalline binary oxides, a number of spinels and perovskites can also be prepared.

The decomposition of supported nitrates can be strongly affected by the nature of the support. Results obtained by Tiernan et al. [20] show that, depending on the properties of support, the decomposition of the supported cobalt nitrate can either be delayed or enhanced. Further, the crystal size of metal nitrates can affect the decomposition. Cseri et al. [21] have reported that the decomposition of metal nitrates supported on a clay was started and was completed at temperatures of $0-40$ and $5-105{ }^{\circ} \mathrm{C}$ lower, respectively, compared with the bulk metal nitrates. Since the decomposition was shifted to lower temperatures pronouncedly for the most amorphous nitrates, it was concluded that this shift was due to the small crystal size of the nitrates. They also noted that some decomposition steps that were observed during the decomposition of bulk nitrates were not observed for the supported samples. In [22] the authors showed that $\mathrm{NiO}$ particles prepared by decomposition of nickel nitrate supported on SBA-15 under the stream of He containing $1 \%$ of NO resulted in the exclusive formation of small particles with a diameter of about $4 \mathrm{~nm}$. Results obtained in [23] revealed that the routes of decomposition of nickel nitrate bulk and supported on alumina are different, especially concerning formation of intermediate phases in the later case.

The literature concerning the decomposition of supported metal nitrates is mainly focused on the properties and possible applications of the final residue-support covered by metal oxides. In this paper, decomposition of chosen $d$-metal nitrates supported on the nanometric alumina was investigated and compared with decomposition of correspondent bulk nitrates. However, the goal of the study was not the final product. The study was focused on the mechanism of the thermal decomposition of bulk and supported nitrates as well as the differences in the decomposition path and they possible reasons.

\section{Materials and methods}

Sample preparation

The samples of supported nitrates were prepared by impregnation the $\mathrm{Al}_{2} \mathrm{O}_{3} \quad(<500 \mathrm{~nm}$, analytical grade,
Aldrich) with an aqueous solution of respective nitrate using the necessary amount of solution for the filling of the support pores. The concentration of the solutions of metal nitrate hydrates: $\mathrm{Ni}\left(\mathrm{NO}_{3}\right)_{2} \cdot 6 \mathrm{H}_{2} \mathrm{O}, \mathrm{Co}\left(\mathrm{NO}_{3}\right)_{2} \cdot 6 \mathrm{H}_{2} \mathrm{O}$, $\mathrm{Zn}\left(\mathrm{NO}_{3}\right)_{2} \cdot 6 \mathrm{H}_{2} \mathrm{O}, \mathrm{Cu}\left(\mathrm{NO}_{3}\right)_{2} \cdot 3 \mathrm{H}_{2} \mathrm{O}$, and $\mathrm{Mn}\left(\mathrm{NO}_{3}\right)_{2} \cdot 6 \mathrm{H}_{2} \mathrm{O}$ (analytical grade, Aldrich) used was $3 \mathrm{~mol} \mathrm{dm}^{-3} .200 \mathrm{mg}$ of $\mathrm{Al}_{2} \mathrm{O}_{3}$ was dispersed in $0.5 \mathrm{~mL}$ of each metal nitrate solution and mixture has been blended for several minutes. Next impregnated alumina supports were dried for twenty-four hours at $30{ }^{\circ} \mathrm{C}$ on air.

The samples of bulk nitrates were prepared by drying respective nitrate hydrate for twenty-four hours at $30^{\circ} \mathrm{C}$ on air. After drying the hydration water content in compounds studied could not be exactly determined, specially for supported samples, that is why we denote water content as $x \mathrm{H}_{2} \mathrm{O}$ per mole of nitrate.

\section{Methods}

Thermal decomposition was performed on an apparatus that enabled simultaneous recording of TG and DTA signals (SDT 2960, TA INSTRUMENTS). This apparatus was connected on-line with a quadrupole mass spectrometer (QMD 300 THERMOSTAR, BALZERS) so that parallel analysis of gaseous products of the reaction was carried out. The energy of the ion source was $70 \mathrm{eV}$ and a Faraday detector was used.

Ion currents for M/q values equal to $18,30,44$, and 46 were monitored (where $\mathrm{M}$ is molecular mass of particle, and $\mathrm{q}$ the particle charge). Selected $\mathrm{M} / \mathrm{q}$ values correspond to the following molecular and fragmentation ions which can be formed during decomposition of nitrates: $\mathrm{H}_{2} \mathrm{O}^{+}$, $\mathrm{NO}^{+}, \mathrm{N}_{2} \mathrm{O}^{+}, \mathrm{NO}_{2}^{+}$. All intensities of ion peaks were first corrected for the background. Measurements were performed in the synthetic air atmosphere $\left(99,999 \%, \mathrm{H}_{2} \mathrm{O}\right.$ content less than $3 \mathrm{ppm}$ ) with flow rate of $9 \mathrm{dm}^{3} \mathrm{~h}^{-1}$. The samples of mass about $15 \mathrm{mg}$ of bulk $\mathrm{Me}\left(\mathrm{NO}_{3}\right)_{2} \cdot \mathrm{xH}_{2} \mathrm{O}$ and $30 \mathrm{mg}$ of supported $\mathrm{Me}\left(\mathrm{NO}_{3}\right)_{2} \cdot \mathrm{xH}_{2} \mathrm{O} / \mathrm{Al}_{2} \mathrm{O}_{3}$ were heated in the platinum crucible with the rate $1 \mathrm{deg} \min ^{-1}$. The gas sampling capillary was placed directly above the vessel. All the data were gathered by an on-line computer system with the commercial software (TA INSTRUMENTS, BALZERS).

The analysis of recorded mass spectrum of gaseous products of decomposition was performed consider the possible products of decomposition along with the fragmentation processes-mainly the origin of $\mathrm{M} / \mathrm{q}=30$ line not only from the NO but also from the fragmentation of $\mathrm{NO}_{2}$ and $\mathrm{N}_{2} \mathrm{O}$. Thus, the $\mathrm{M} / \mathrm{q}=18$ and $\mathrm{M} / \mathrm{q}=46$ ion current lines describe liberation of $\mathrm{H}_{2} \mathrm{O}$ and $\mathrm{NO}_{2}$, respectively. However, small amounts of $\mathrm{NO}(\mathrm{M} / \mathrm{q}=30)$ and tracers of $\mathrm{N}_{2} \mathrm{O}(\mathrm{M} / \mathrm{q}=44)$ were also observed in the gaseous products of decomposition. Moreover, the shape of 
Fig. 1 TG (a) and DTA (b) results of decomposition of cobalt nitrate bulk and supported on $\mathrm{Al}_{2} \mathrm{O}_{3}$ and $\mathrm{MS}$ signals of $\mathrm{H}_{2} \mathrm{O}(\mathbf{c})$ and $\mathrm{NO}_{2}(\mathbf{d})$

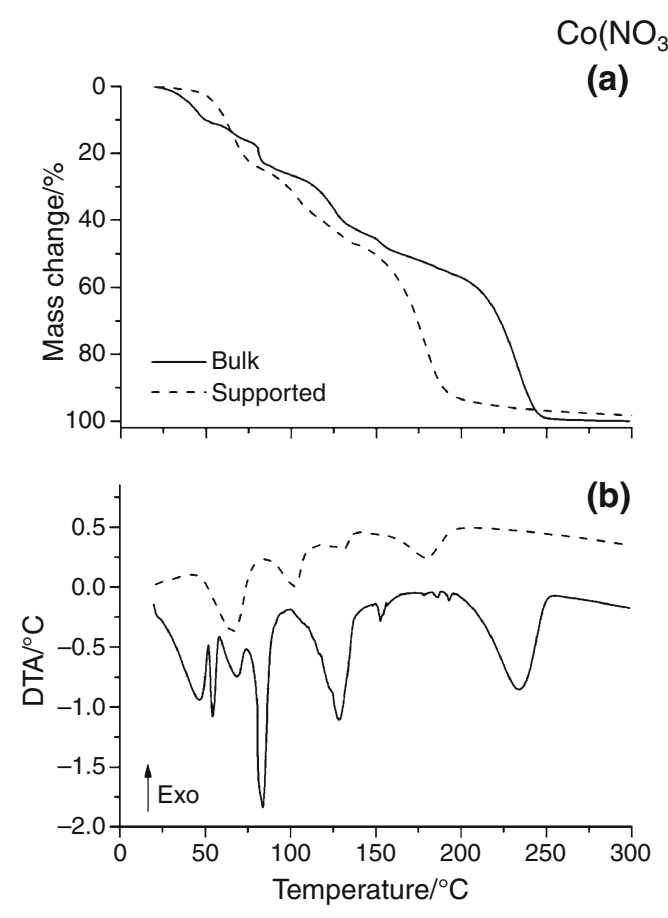

$\mathrm{Co}\left(\mathrm{NO}_{3}\right)_{2} \cdot \mathrm{XH}_{2} \mathrm{O}$

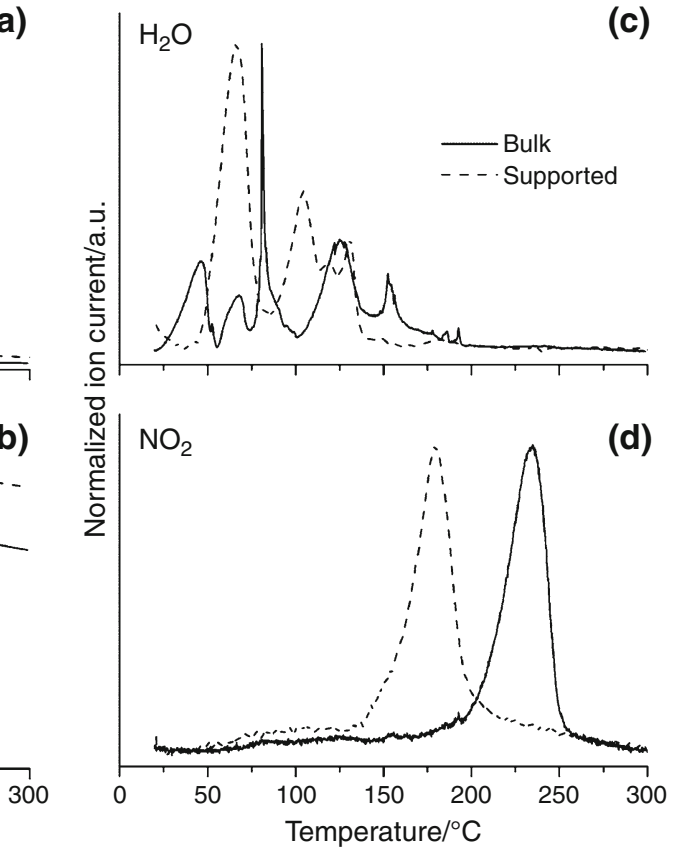

$\mathrm{M} / \mathrm{q}=30,44$, and 46 ion current lines suggest that NO, $\mathrm{N}_{2} \mathrm{O}$, and $\mathrm{NO}_{2}$ are liberated during the same stages of decomposition therefore they all are the results of nitrate groups decomposition. To minimize the numbers of ion current lines presented in the figures, the $\mathrm{M} / \mathrm{q}=46$ line was chosen to present not only the emission of $\mathrm{NO}_{2}$ but also the products of nitrate groups decomposition in general.

The composition of initial sample, intermediates, and residue was analysed by X'Pert Pro X-ray diffractometer (PHILIPS Panalytical) using $\mathrm{CuK} \alpha$ radiation.

The morphological characteristics of samples was investigated using JEOL JSM 5400 scanning electron microscope.

\section{Results \\ $\mathrm{Co}\left(\mathrm{NO}_{3}\right)_{2} \cdot \mathrm{xH}_{2} \mathrm{O}$}

Thermal decomposition of bulk cobalt nitrate hydrate proceeds in several not well-separated stages (Fig. 1). The dehydration starts at room temperature $\left(25^{\circ} \mathrm{C}\right)$ and occurs in five steps that is clearly seen on DTA curve (Fig. 1b) and on mass spectral signals (Fig. 1c). Dehydration associated with several DTA peaks indicates the complexity of dehydration process and proves the formation of series of lower hydrates. The composition of these lower hydrates cannot be calculated based on mass loss because none of them forms the stable phase at the conditions of experiment. At about $175{ }^{\circ} \mathrm{C}$ dehydration finishes (MS signal for $\mathrm{H}_{2} \mathrm{O}$ in Fig. 1c disappears) and decomposition of nitrates begins (MS signal for $\mathrm{NO}_{2}$ appears). However, small amount of nitrogen oxides are evolved below $175{ }^{\circ} \mathrm{C}$ what suggests that during dehydration decomposition of nitrate groups proceeds probably on the material surface, which is highly probable for nitrates. At about $250{ }^{\circ} \mathrm{C}$ bulk cobalt nitrate is fully decomposed. The steps on TG curve as well as endothermic effects on DTA curve in the temperature range of $20-250{ }^{\circ} \mathrm{C}$ are connected with corresponding effects on mass spectra.

In the case of cobalt nitrate supported on $\mathrm{Al}_{2} \mathrm{O}_{3}$ dehydration proceeds in three stages. It starts at about $40{ }^{\circ} \mathrm{C}$ and is completed at $140{ }^{\circ} \mathrm{C}$, that is temperature $35^{\circ} \mathrm{C}$ lower than the end of dehydration of bulk cobalt nitrate. The nitrogen oxides start to release just after dehydration completes at $140{ }^{\circ} \mathrm{C}$ which is temperature about thirty-five degrees lower than that for the bulk cobalt nitrate. Though traces of nitrogen oxides are evolved during the dehydration, similar as it was observed for bulk cobalt nitrate. The decomposition of supported cobalt nitrate is finished at about $210{ }^{\circ} \mathrm{C}$. The SEM microphotograph of the residue is shown in Fig. 2a.

The final product of bulk cobalt nitrate decomposition is $\mathrm{Co}_{3} \mathrm{O}_{4}$, which was confirmed by XRD analysis (not shown here) and stays in agreement with results presented in the literature $[22,24]$. Decomposition of cobalt nitrate supported on $\mathrm{Al}_{2} \mathrm{O}_{3}$ leads to $\mathrm{CoAl}_{2} \mathrm{O}_{4}$ spinel as the final product at the temperature $210{ }^{\circ} \mathrm{C}$ (Fig. 2b). As it is in detail described in the literature, the decomposition of cobalt 
Fig. 2 SEM microphotograph and XRD patterns of thermal decomposition residue at $350{ }^{\circ} \mathrm{C}$ of alumina supported $\mathrm{Co}\left(\mathrm{NO}_{3}\right)_{2} \cdot \mathrm{xH}_{2} \mathrm{O}$
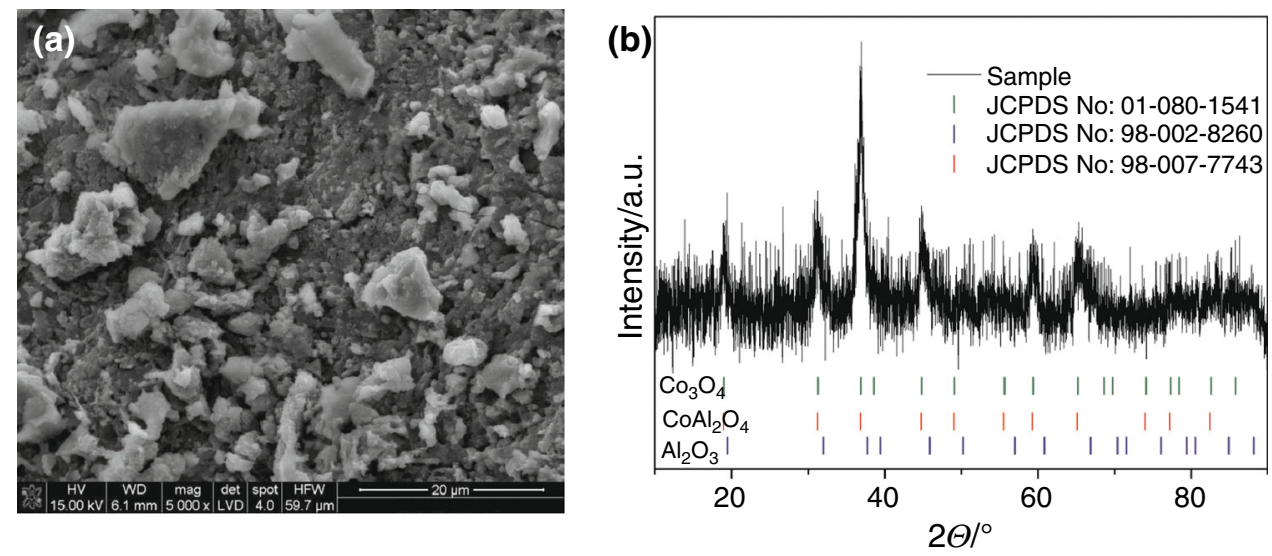

Fig. 3 TG (a) and DTA (b) results of decomposition of nickel nitrate bulk and supported on $\mathrm{Al}_{2} \mathrm{O}_{3}$ and $\mathrm{MS}$ signals of $\mathrm{H}_{2} \mathrm{O}(\mathbf{c})$ and $\mathrm{NO}_{2}(\mathbf{d})$

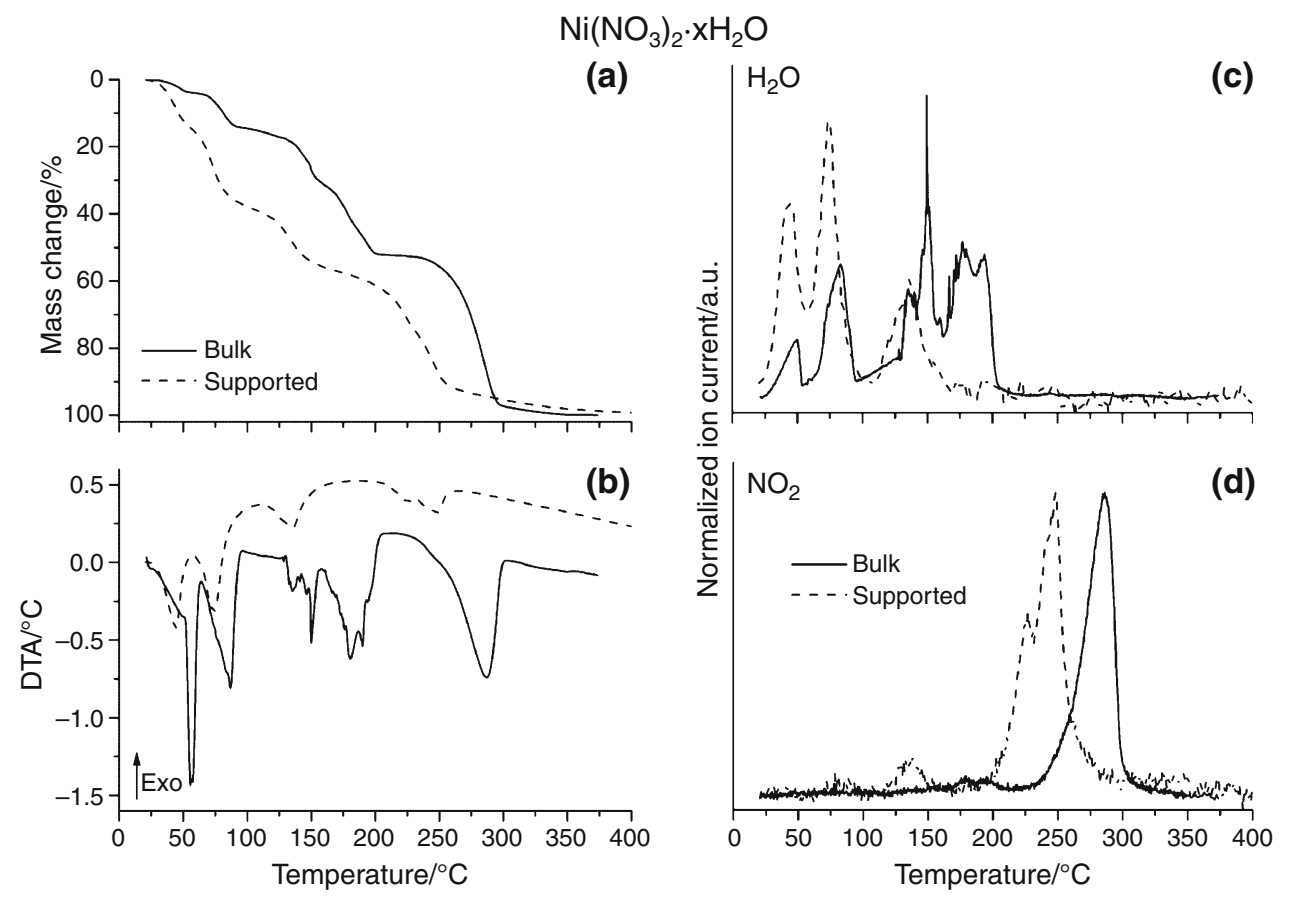

nitrate on alumina leads to oxide mixture $\left(\mathrm{Al}_{2} \mathrm{O}_{3}\right.$ and $\left.\mathrm{Co}_{3} \mathrm{O}_{4}\right)$ or $\mathrm{CoAl}_{2} \mathrm{O}_{4}$ spinel, depending on the support synthesis method [25]. However, highly dispersed support can imply the spinel formation even in the relatively low temperature.

$$
\mathrm{Ni}\left(\mathrm{NO}_{3}\right)_{2} \cdot \mathrm{xH}_{2} \mathrm{O}
$$

The decomposition of nickel nitrate hydrate (Fig. 3) proceeds in several stages like in the case of cobalt nitrate. The dehydration of bulk nickel nitrate hydrate as well as supported one begins at room temperature, but the course of dehydration in both cases is different. Dehydration of bulk nickel nitrate goes through several not well-separated stages and finishes at about $210^{\circ} \mathrm{C}$. For the supported nickel nitrate four well-separated stages of dehydration are observed and the release of hydration water is completed at $175^{\circ} \mathrm{C}$, which is reflected on MS signal of $\mathrm{H}_{2} \mathrm{O}$ (Fig. $3 \mathrm{c}$ ).

The decomposition of anhydrous nitrate obtained from bulk nickel nitrate hydrate is one-stage process occurring between 225 and $310{ }^{\circ} \mathrm{C}$. The MS signals for $\mathrm{H}_{2} \mathrm{O}$ and $\mathrm{NO}_{2}$ obtained during decomposition of supported nickel nitrate reveal evolution of traces of nitrogen oxides at about $125^{\circ} \mathrm{C}$ that is before completion of dehydration. The main decomposition of nitrate groups of supported nickel nitrate begins at $190{ }^{\circ} \mathrm{C}$ and is two-stage process, which is confirmed by DTA peaks and MS signals (Fig. 3d). At $280{ }^{\circ} \mathrm{C}$, the MS signal for nitrogen oxide disappears that indicates the completion of nitrate groups decomposition; however, on the TG curve (Fig. 3a) the slight decrease of sample mass to $375{ }^{\circ} \mathrm{C}$ can be seen, resulting probably from the 
Fig. 4 SEM microphotograph and XRD patterns of thermal decomposition residue at $400{ }^{\circ} \mathrm{C}$ of alumina supported $\mathrm{Ni}\left(\mathrm{NO}_{3}\right)_{2} \cdot \mathrm{xH}_{2} \mathrm{O}$
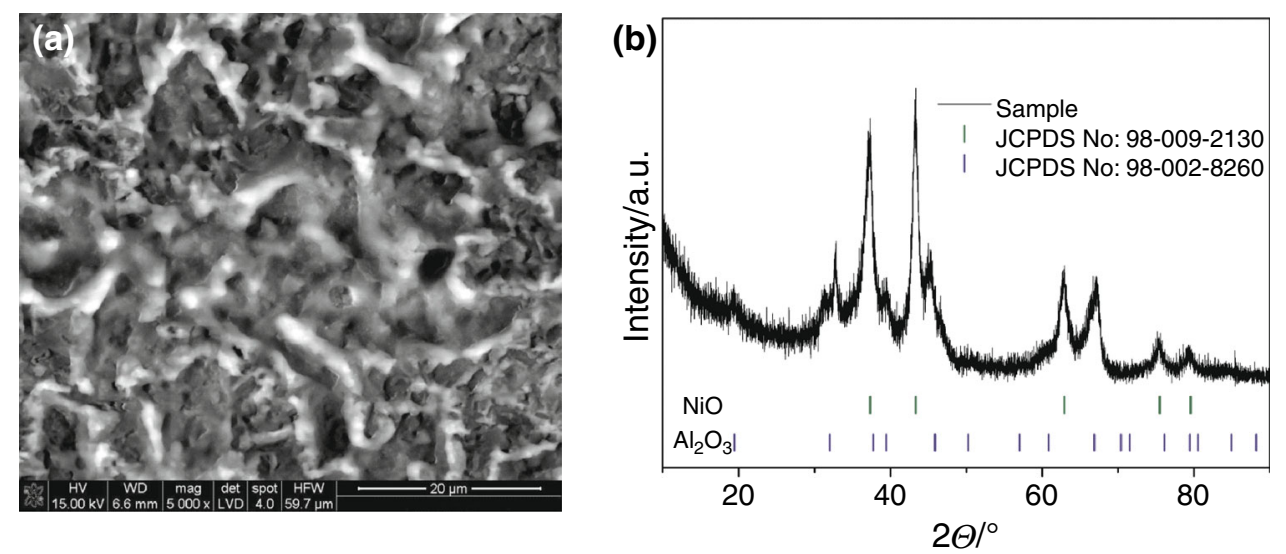

Fig. 5 TG (a) and DTA (b) results of decomposition of manganese nitrate bulk and supported on $\mathrm{Al}_{2} \mathrm{O}_{3}$ and $\mathrm{MS}$ signals of $\mathrm{H}_{2} \mathrm{O}(\mathbf{c})$ and $\mathrm{NO}_{2}(\mathbf{d})$

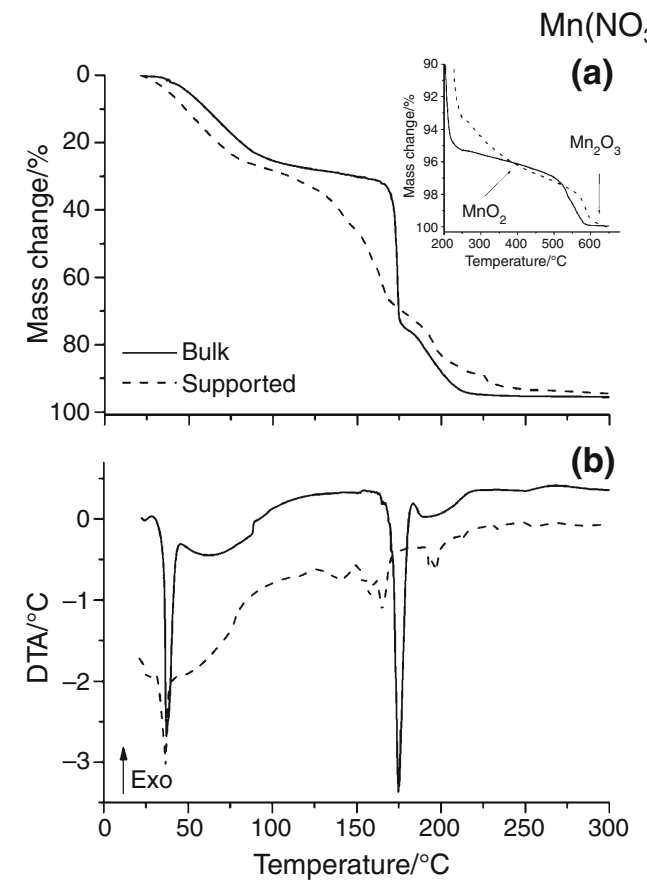

(c)
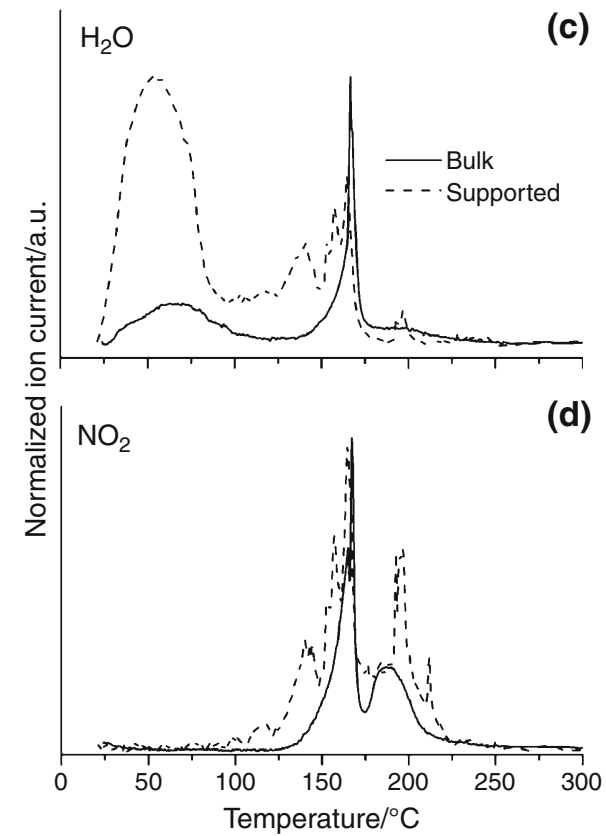

slow desorption of gaseous product from the support surface.

The final product of nickel nitrate hydrate decomposition of both samples is nickel oxide NiO. Figure 4 shows SEM microphotograph and the results of XRD analysis of the decomposition residue of nickel nitrate supported on $\mathrm{Al}_{2} \mathrm{O}_{3}$.

\section{$\mathrm{Mn}\left(\mathrm{NO}_{3}\right)_{2} \cdot \mathrm{xH}_{2} \mathrm{O}$}

Decomposition of bulk manganese nitrate hydrate is a multistage process with overlapping steps (Fig. 5). As can be seen on DTA curve (Fig. 5b) bulk compound melts at about $35^{\circ} \mathrm{C}$ and next undergoes dehydration. Before completing dehydration around $135{ }^{\circ} \mathrm{C}$ degradation of nitrate groups begins. This statement is based on MS spectra (Fig. 5c-d) - it is seen that between 135 and $175^{\circ} \mathrm{C}$ the rest of $\mathrm{H}_{2} \mathrm{O}$ evolves together with $\mathrm{NO}_{2}$. The conclusion is that anhydrous manganese nitrate is not formed during decomposition. The residue of decomposition at $300{ }^{\circ} \mathrm{C}$ is $\mathrm{MnO}_{2}$.

As can be seen on DTA/TG curves (Fig. 5), decomposition of nitrate supported on $\mathrm{Al}_{2} \mathrm{O}_{3}$ starts at about $110{ }^{\circ} \mathrm{C}$ which is the temperature lower than that for bulk substance. Decomposing occurs through overlapping stages not separated on TG curves, which are preceded by melting of sample. Mass spectrum analysis showed that below $110^{\circ} \mathrm{C}$ water is the only volatile product of decomposition. Above $110{ }^{\circ} \mathrm{C}$, several steps of decomposition occur which is specially clearly seen on DTA curve (Fig. 5b). Between 110 and $210{ }^{\circ} \mathrm{C}$, evolution of $\mathrm{NO}_{2}$ together with $\mathrm{H}_{2} \mathrm{O}$ is observed similarly as for bulk manganese nitrate hydrate; however, 
Fig. 6 SEM microphotograph and XRD patterns of thermal decomposition residue at $600{ }^{\circ} \mathrm{C}$ of alumina supported $\mathrm{Mn}\left(\mathrm{NO}_{3}\right)_{2} \cdot \mathrm{xH}_{2} \mathrm{O}$

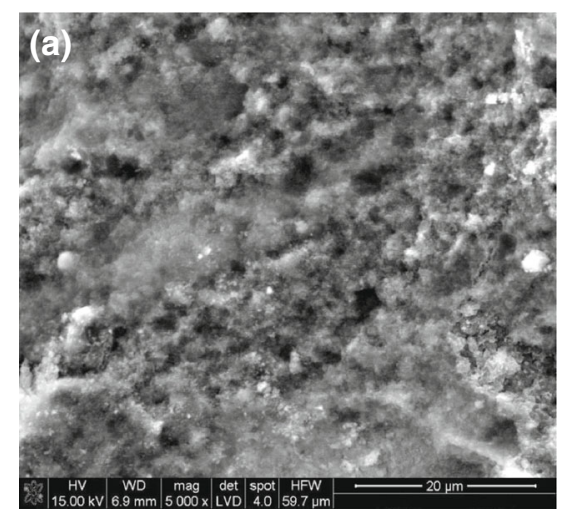

Fig. 7 TG (a) and DTA (b) results of decomposition of zinc nitrate bulk and supported on $\mathrm{Al}_{2} \mathrm{O}_{3}$ and $\mathrm{MS}$ signals of $\mathrm{H}_{2} \mathrm{O}(\mathbf{c})$ and $\mathrm{NO}_{2}(\mathbf{d})$

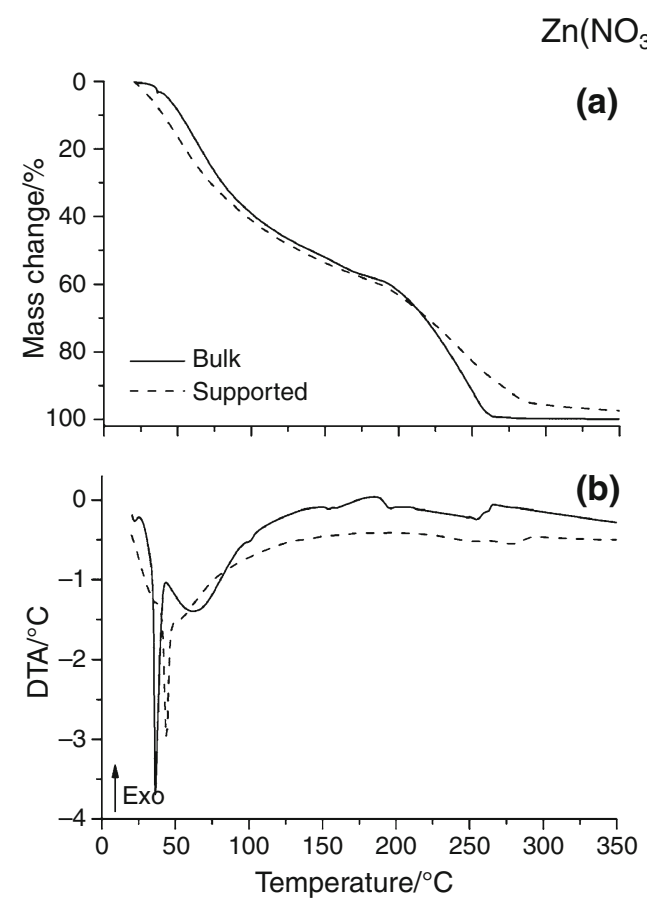

a)

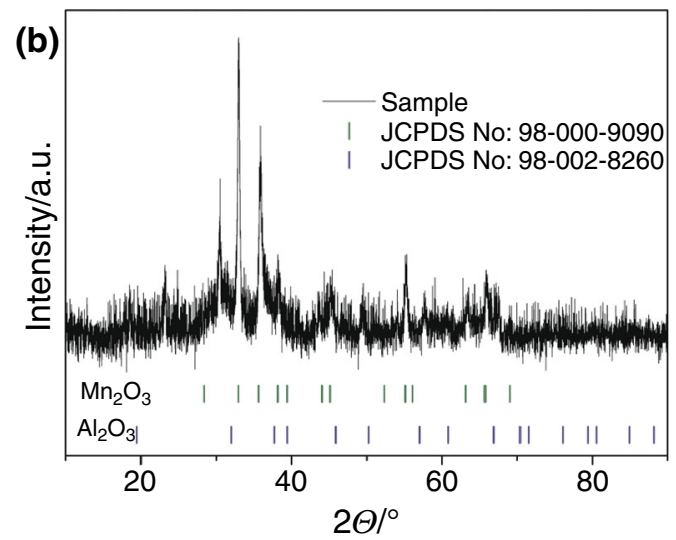

$\left(\mathrm{NO}_{3}\right)_{2} \cdot \mathrm{xH}_{2} \mathrm{O}$

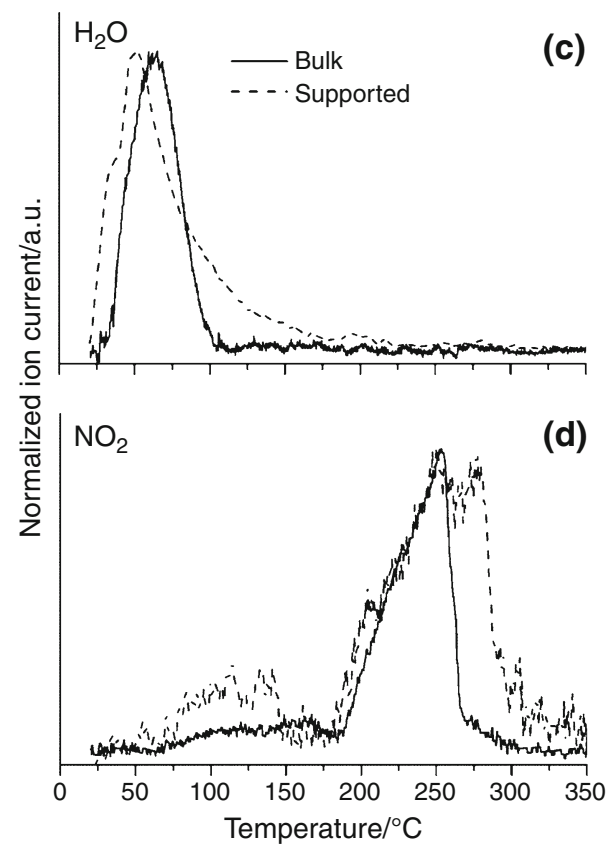

the range of temperature is broadened. The final product of thermal decomposition of manganese nitrate is $\mathrm{MnO}_{2}$. However, as it is seen on Fig. 5a manganese(IV) oxide can be decomposed to $\mathrm{Mn}_{2} \mathrm{O}_{3}$ at $600{ }^{\circ} \mathrm{C}$. Furthermore, the results of XRD analysis (Fig. 6b) of solid residue of decomposition of manganese(II) nitrate supported on $\mathrm{Al}_{2} \mathrm{O}_{3}$ taken from the temperature $600{ }^{\circ} \mathrm{C}$ confirm decomposition to mixture of manganese(III) and aluminium oxides. SEM microphotograph and XRD results (Fig. 6) suggest that both $\mathrm{Al}_{2} \mathrm{O}_{3}$ and $\mathrm{Mn}_{2} \mathrm{O}_{3}$ exhibit a low degree of crystallinity.

\section{$\mathrm{Zn}\left(\mathrm{NO}_{3}\right)_{2} \cdot \mathrm{xH}_{2} \mathrm{O}$}

Bulk zinc nitrate hydrate (Fig. 7) starts to dehydrate at about $30{ }^{\circ} \mathrm{C}$. Dehydration is accompanied by melting of a compound at $35^{\circ} \mathrm{C}$ (sharp, endothermic DTA peak on
Fig. 7). According to MS analysis, signal from water disappears at $120{ }^{\circ} \mathrm{C}$ which means that dehydration finishes at this temperature. Decomposition of nitrate groups starts at $75^{\circ} \mathrm{C}$ and is finished at $265^{\circ} \mathrm{C}$ when $\mathrm{ZnO}$ as final product is formed. However, when we analyse the shape of TG curve, the stage of dehydration is not separated from the stage of nitrate groups decomposition. Decomposition of zinc nitrate hydrate supported on $\mathrm{Al}_{2} \mathrm{O}_{3}$ proceeds at the beginning similarly to the decomposition of bulk material. Dehydration and melting of hydrate in a comparable temperature (around $40^{\circ} \mathrm{C}$ ) can be noticed. The differences show when decomposition of nitrate groups starts. $\mathrm{NO}_{2}$ was detected in gaseous products starting from $60{ }^{\circ} \mathrm{C}$ together with $\mathrm{H}_{2} \mathrm{O}$. The second stage of nitrogen oxides evolution appeared at $175^{\circ} \mathrm{C}$. The decomposition of supported $\mathrm{Zn}\left(\mathrm{NO}_{3}\right)_{2}$ finished about $320^{\circ} \mathrm{C}$. 
Fig. 8 SEM microphotograph and XRD patterns of thermal decomposition residue at $350{ }^{\circ} \mathrm{C}$ of alumina supported $\mathrm{Zn}\left(\mathrm{NO}_{3}\right)_{2} \cdot \mathrm{xH}_{2} \mathrm{O}$
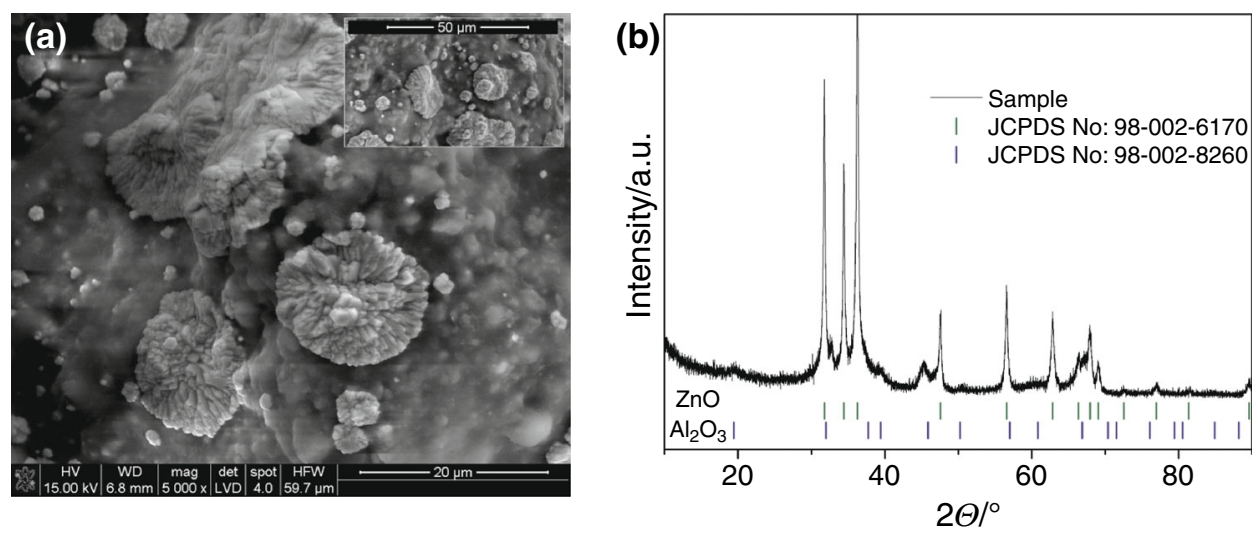

Fig. 9 TG (a) and DTA (b) results of decomposition of copper nitrate bulk and supported on $\mathrm{Al}_{2} \mathrm{O}_{3}$ and $\mathrm{MS}$ signals of $\mathrm{H}_{2} \mathrm{O}(\mathbf{c})$ and $\mathrm{NO}_{2}(\mathbf{d})$

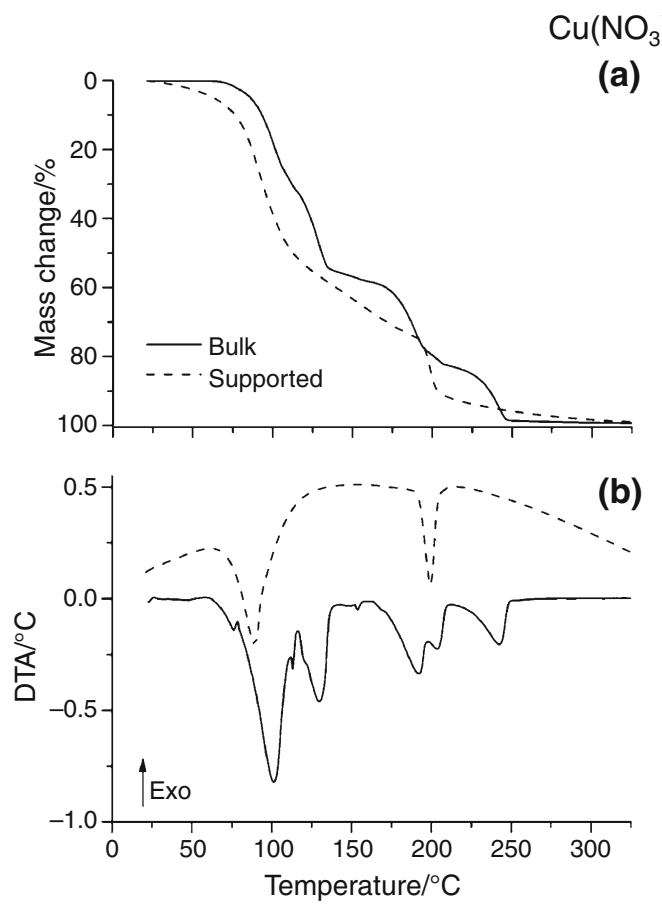

(c)

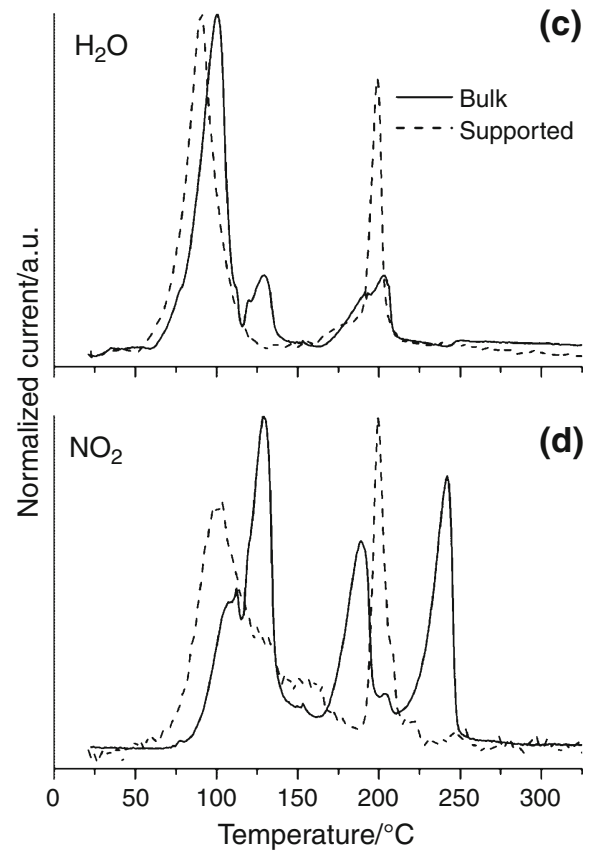

The final product of decomposition, $\mathrm{ZnO}$, forms on the surface of $\mathrm{Al}_{2} \mathrm{O}_{3}$ flower-shaped grains which actually consist of wurtzite-type crystals (Fig. 8).

$$
\mathrm{Cu}\left(\mathrm{NO}_{3}\right)_{2} \cdot \mathrm{xH}_{2} \mathrm{O}
$$

$\mathrm{Cu}\left(\mathrm{NO}_{3}\right)_{2}$ hydrate decomposes by overlapping stages. As can be seen in (Fig. 9) bulk $\mathrm{Cu}\left(\mathrm{NO}_{3}\right)_{2}$ hydrate starts to lose mass at about $75{ }^{\circ} \mathrm{C}$ in several not separated stages. Almost at the temperature of the beginning of dehydration, nitrogen oxides starts to evolve (Fig. 9d). The dehydration and decomposition of nitrate groups proceed simultaneously to $225{ }^{\circ} \mathrm{C}$ when dehydration finishes. Releasing the water vapour at temperatures about $200{ }^{\circ} \mathrm{C}$ suggests evolving constitution water rather that hydration one. Especially as
$\mathrm{Cu}\left(\mathrm{NO}_{3}\right)_{2} \cdot 3 \mathrm{Cu}(\mathrm{OH})_{2}$ or $\mathrm{Cu}_{2}(\mathrm{OH})_{3}\left(\mathrm{NO}_{3}\right)$ according to the literature can be identified as solid intermediate during copper nitrate decomposition [26, 27]. Complete decomposition of bulk cooper nitrate hydrate finishes at $250{ }^{\circ} \mathrm{C}$. It should be noticed that the last stage of decomposition $\left(225-250{ }^{\circ} \mathrm{C}\right)$ is combined only with degradation of nitrates groups.

It should be noticed that the mechanism of decomposition of copper nitrate supported on $\mathrm{Al}_{2} \mathrm{O}_{3}$ is significantly different as the decomposition of bulk material. In case of supported $\mathrm{Cu}\left(\mathrm{NO}_{3}\right)_{2}$ hydrate two stages of dehydration can be observed. Dehydration starts at $60{ }^{\circ} \mathrm{C}$ and is associated with one endothermic peak on DTA (Fig. 9b) and adequate signal on MS spectrum (Fig. 9c). The second stage of dehydration occurs between 175 and $225{ }^{\circ} \mathrm{C}$. Decomposition of nitrate 
Fig. 10 SEM microphotograph and XRD patterns of thermal decomposition residue at $350{ }^{\circ} \mathrm{C}$ of alumina supported $\mathrm{Cu}\left(\mathrm{NO}_{3}\right)_{2} \cdot \mathrm{xH}_{2} \mathrm{O}$
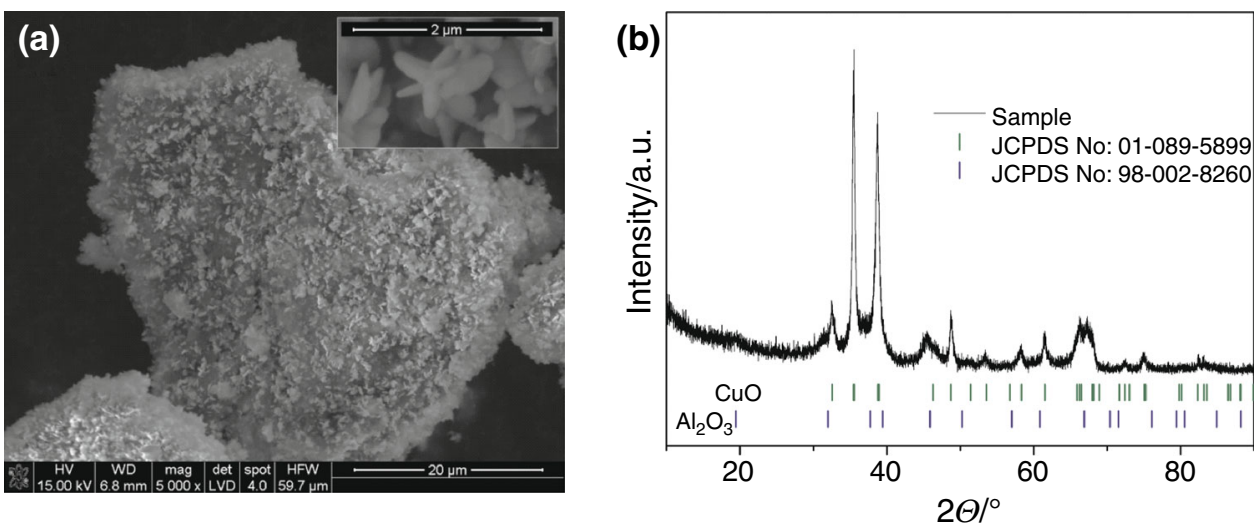

Table 1 Comparison of dehydration and decomposition temperatures of $d$-metal nitrates

\begin{tabular}{|c|c|c|c|c|c|c|}
\hline \multirow[t]{2}{*}{ Element } & \multicolumn{3}{|c|}{ Bulk } & \multicolumn{3}{|c|}{ Supported } \\
\hline & $T_{\mathrm{deh}}$ & $T_{\text {decomp }}$ & $T_{\text {fin }}$ & $T_{\mathrm{deh}}$ & $T_{\text {decomp }}$ & $T_{\text {fin }}$ \\
\hline $\mathrm{Zn}$ & 30 & 75 & 265 & 40 & 60 & 320 \\
\hline $\mathrm{Cu}$ & 75 & 90 & 250 & 60 & 60 & 225 \\
\hline $\mathrm{Mn}$ & 35 & 135 & 220 & 35 & 110 & 225 \\
\hline Co & 25 & 175 & 250 & 40 & 140 & 210 \\
\hline $\mathrm{Ni}$ & 25 & 225 & 310 & 25 & 190 & 280 \\
\hline
\end{tabular}

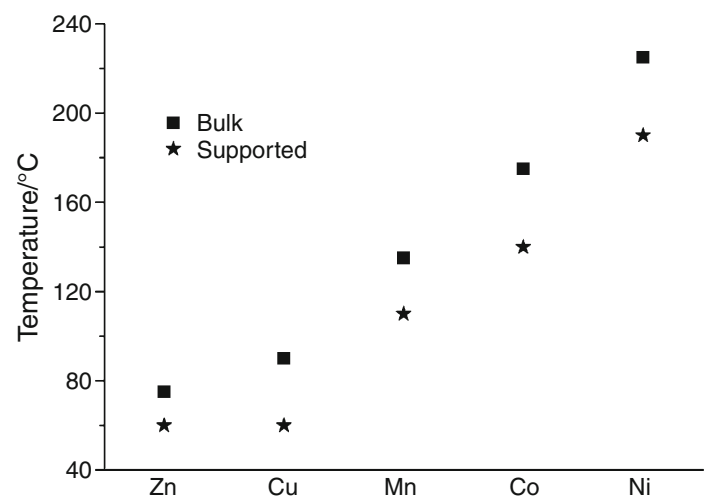

Fig. 11 Comparison of decomposition temperatures of $d$-metal nitrates bulk and supported on $\mathrm{Al}_{2} \mathrm{O}_{3}$

groups proceeds at the same temperature ranges as dehydration does. Thus, elimination of water from the structure is always accompanied with degradation of nitrate groups even in the relatively low temperature (about $70{ }^{\circ} \mathrm{C}$ ). At the temperature of $225{ }^{\circ} \mathrm{C}$ copper nitrate supported on $\mathrm{Al}_{2} \mathrm{O}_{3}$ is fully decomposed.

The final product of $\mathrm{Cu}\left(\mathrm{NO}_{3}\right)_{2}$ hydrate decomposition in both cases is monoclinic $\mathrm{CuO}$ (Fig. 10b). CuO crystals which were formed on the $\mathrm{Al}_{2} \mathrm{O}_{3}$ support have a needleshaped form (Fig. 10a).
Table 2 Atomic properties of $d$-metals [28]

\begin{tabular}{lllll}
\hline Metal & $\begin{array}{l}\text { Ionic } \\
\text { radius/ } \\
\text { pm }\end{array}$ & $\begin{array}{l}\text { Covalent } \\
\text { radius/ } \\
\text { pm }\end{array}$ & $\begin{array}{l}\text { Electronegativity/ } \\
\text { Pauling scale }\end{array}$ & $\begin{array}{l}\text { Electroconfig. of } \\
\mathrm{Me}^{2+} d \text { electron } \\
\text { number }\end{array}$ \\
\hline $\mathrm{Zn}$ & 83 & 125 & 1.65 & 10 \\
$\mathrm{Cu}$ & 73 & 117 & 1.9 & 9 \\
$\mathrm{Mn}$ & 91 & 117 & 1.55 & 5 \\
$\mathrm{Co}$ & 78 & 116 & 1.88 & 7 \\
$\mathrm{Ni}$ & 74 & 115 & 1.91 & 8 \\
\hline
\end{tabular}

\section{Discussion and conclusions}

Analysis of the temperatures of the beginning of dehydration $\left(T_{\mathrm{deh}}\right)$ and temperatures of the end of decomposition $\left(T_{\text {fin }}\right)$ of adequate bulk and supported nitrates (Table 1) leads to conclusion that there are no significant differences and correlations between those temperatures.

In case of temperatures of the beginning of decomposition ( $\left.T_{\text {decomp }}\right)$, the differences are not significant as well but we observe the general dependence that temperature of decomposition of supported nitrate is lower than temperature of decomposition of adequate bulk nitrate (Fig. 11). The lowest temperature of decomposition occurs for $\mathrm{Cu}\left(\mathrm{NO}_{3}\right)_{2}$, and the highest for $\mathrm{Ni}\left(\mathrm{NO}_{3}\right)_{2}$.

No significant correlation between the atomic properties of $d$-metals, listed in Table 2, and temperature of decomposition were found, may be with one exception concerning some slight correlation between covalent radius of cation and the $T_{\text {decomp. }}$. The lack of significant correlations seems to indicate that the main role in decomposition of studied nitrates plays processes which occur in the nitrate ion; however, the modifications in the electron and geometric structure of $\mathrm{NO}_{3}{ }^{-}$ion resulted from its different surroundings can be responsible for changes in the picture of decomposition of individual nitrates.

Acknowledgements This work has been performed with the financial support of the Polish Ministry of Science and Higher Education, under the Grant No. 11.11.160.438. 
Open Access This article is distributed under the terms of the Creative Commons Attribution License which permits any use, distribution, and reproduction in any medium, provided the original author(s) and the source are credited.

\section{References}

1. Li J, Changa H, Maa L, Haoa J, Yang RT. Low-temperature selective catalytic reduction of $\mathrm{NO}_{x}$ with $\mathrm{NH}_{3}$ over metal oxide and zeolite catalysts-a review. Catal Today. 2011;175:147-56.

2. Lamonier JF, Labaki M, Wyrwalski F, Siffert S, Aboukais A. Thermal behaviour and catalytic properties towards propene combustion of zirconia modified by different first row transition metals. J Anal Appl Pyrolysis. 2008;8:20-6.

3. Nissinen T, Leskelä M, Gasik M, Lamminen J. Decomposition of mixed $\mathrm{Mn}$ and Co nitrates supported on carbon. Thermochim Acta. 2005;427:155-61.

4. Moon J, Awano M, Takagi H, Fujishiro Y. Synthesis of nanocrystalline manganese oxide powders: influence of hydrogen peroxide on particle characteristics. J Mater Res. 1999;14:4594-601.

5. Schwickardi M, Johann T, Schmidt W, Schüth F. High-surfacearea oxides obtained by an activated carbon route. Chem Mater. 2002;14:3913-9.

6. Ruiz ML, Lick ID, Ponzi MI, Castellón ER, Jiménez-López A, Ponzi EN. Thermal decomposition of supported lithium nitrate catalysts. Thermochim Acta. 2010;499:21-6.

7. Szczygieł I, Winiarska K. Synthesis and characterization of manganese-zinc ferrite obtained by thermal decomposition from organic precursors. J Therm Anal Calorim. 2014;115:471-7.

8. Barvinschi P, Stefanescu O, Dippong T, Sorescu S, Stefanescu M. $\mathrm{CoFe}_{2} \mathrm{O}_{4} / \mathrm{SiO}_{2}$ nanocomposites by thermal decomposition of some complex combinations embedded in hybrid silica gels. J Therm Anal Calorim. 2013;112:447-53.

9. Stoia M, Barvinschi P, Barbu-Tudoran L. Thermal decomposition of metal nitrates PVA-TEOS gels for obtaining M(II) ferrite/ silica nanocomposites. J Therm Anal Calorim. 2013;113:21-30.

10. Nohman AKH, Ismail HM, Hussein GAM. Thermal and chemical events in the decomposition course of manganese compounds. J Anal Appl Pyrolysis. 1995;34:265-78.

11. Małecki A, Gajerski R, Łabuś S, Prochowska-Klisch B, Wojciechowski KT. Mechanism of the thermal decomposition of $d$ metal nitrates hydrates. J Therm Anal Calorim. 2000;60:17-23.

12. Małecki A, Gajerski R, Prochowska-Klisch B, Podgórecka A. The mechanism of thermal decomposition of $\mathrm{Co}\left(\mathrm{NO}_{3}\right)_{2} \cdot 2 \mathrm{H}_{2} \mathrm{O}$. J Therm Anal Calorim. 1988;34:203-9.

13. Małecki A, Gajerski R, Łabuś S, Prochowska-Klisch B. Mechanism of thermal decomposition of $\mathrm{Ni}\left(\mathrm{NO}_{3}\right)_{2} \cdot 2 \mathrm{H}_{2} \mathrm{O}$. J Therm Anal Calorim. 1993;39:545-50.

14. Małecki A, Małecka B, Gajerski R, Łabuś S. Thermal decomposition of chromium(III) nitrate(V) nonahydrate. Different chromium oxides $\mathrm{CrO1}, 5+\mathrm{y}$ formation. J Therm Anal Calorim. 2003;72:135-44.
15. Małecka B, Gajerski R, Małecki A, Wierzbicka M, Olszewski P. Mass spectral studies on the mechanism of thermal decomposition of $\mathrm{Zn}\left(\mathrm{NO}_{3}\right)_{2} \cdot \mathrm{nH}_{2} \mathrm{O}$. Thermochim Acta. 2003;404:125-32.

16. Yuvaraj S, Fan-Yuan L, Tsong-Huei C, Chuin-Tih Y. Thermal decomposition of metal nitrates in air and hydrogen environments. J Phys Chem B. 2003;107:1044-7.

17. Gallagher PK, Schrey F, Prescott B. The thermal decomposition of aqueous manganese (II) nitrate solution. Thermochim Acta. 1971;2:405-12.

18. Galdeano NF, Carrascull AL, Ponzi MI, Lick ID, Ponzi EN. Catalytic combustion of particulate matter. Catalysts of alkaline nitrates supported on hydrous zirconium. Thermochim Acta. 2004;421:117-21.

19. Pasel J, Käßner P, Montanari B, Gazzano M, Vaccari A, Makowski W, Lojewski T, Dziembaj R, Papp H. Transition metal oxides supported on active carbons as low temperature catalysts for the selective catalytic reduction (SCR) of $\mathrm{NO}$ with $\mathrm{NH}_{3}$. Appl Catal B-Environ. 1998;18:199-213.

20. Tiernan MJ, Fesenko EA, Barnes PA, Parkes GMB, Ronane M. The application of CRTA and linear heating thermoanalytical techniques to the study of supported cobalt oxide methane combustion catalysts. Thermochim Acta. 2001;379:163-75.

21. Cseri T, Bekassy S, Kenessey G, Liptay G, Figueras F. Characterization of metal nitrates and clay supported metal nitrates by thermal analysis. Thermochim Acta. 1996;288:137-54.

22. Sietsma JRA, Meeldijk JD, den Breejen JP, Versluijs-Helder M, van Dillen AJ, de Jongh PE, de Jong KP. The preparation of supported $\mathrm{NiO}$ and $\mathrm{Co}_{3} \mathrm{O}_{4}$ nanoparticles by the nitric oxide controlled thermal decomposition of nitrates. Angew Chem Int Ed. 2007;46:4545-7.

23. Marturano MA, Aglietti EF, Ferretti OA. Nature of $\mathrm{Ni}-\mathrm{Al}$ developed phases during thermal activation in relation to the preparation techniques. Part I: calcination. Thermochim Acta. 1999;336:47-54.

24. Brockner W, Ehrhardt C, Gjikaj M. Thermal decomposition of nickel nitrate hexahydrate, $\mathrm{Ni}\left(\mathrm{NO}_{3}\right)_{2} \cdot 6 \mathrm{H}_{2} \mathrm{O}$, in comparison to $\mathrm{Co}\left(\mathrm{NO}_{3}\right)_{2} \cdot 6 \mathrm{H}_{2} \mathrm{O}$ and $\mathrm{Ca}\left(\mathrm{NO}_{3}\right)_{2} \cdot 4 \mathrm{H}_{2} \mathrm{O}$. Thermochim Acta. 2007;456:64-8.

25. Bolt PH, Habraken FHPM, Geus JW. Formation of nickel, cobalt, copper, and iron aluminates from $\alpha$ - and $\gamma$-alumina-supported oxides: a comparative study. J Solid State Chem. 1998;135: $59-69$.

26. Morozov IV, Znamenkov KO, Korenev YM, Shlyakhtin OA. Thermal decomposition of $\mathrm{Cu}\left(\mathrm{NO}_{3}\right)_{2} \cdot 3 \mathrm{H}_{2} \mathrm{O}$ at reduced pressures. Thermochim Acta. 2003;403:173-9.

27. L'vov BV, Novichikhin AV. Mechanism of thermal decomposition of hydrated copper nitrate in vacuo. Spectrochim Acta B. 1995;50:1459-68.

28. Lide DR. CRC Handbook of Chemistry and Physics. 89th ed. Boca Raton: CRC Press Taylor Francis Group; 2008. 